\title{
THE CONSTITUTION AND INEQUALITY OF RIGHTS.
}

\author{
BY EDWIN BURRITT SMTTH,
}

OF THE CHICAGO BAR.

That the United States may acquire territory, as raw material for future States, is unquestioned; that the United States acquired whatever title Spain then had to Porto Rico and the Philippines, by the Treaty of Paris, is conceded. What is disputed is the novel claim that the United States may adopt and enforce, in the government of these islands, the principle of the inequality of rights. All our prior acquisitions of territory were sought for settlement by our people, to become the home of our institutions, to expand the domain of equal rights, to enlarge the area of constitutional liberty.

A vision of the equality of rights was the inspiration of our national life. The immortal declaration that all men are created equal-that they are endowed by the Creator with certain inalienable rights, among which are life, liberty, and the pursuit of happiness-fitly expressed the ideal of democracy. To achieve this ideal we have striven for more than a century. In its pursuit we have organized, established constitutions, legislated, administered.

The great purpose of the Constitution was to establish equality of personal rights. To this end it commands that commerce be free and its necessary regulations uniform throughout the United States. Authority to tax rests upon representation. Congress may lay and collect taxes, duties, imposts, and excises: but taxes must be according to population, and "all duties, imposts, and excises shall be uniform throughout the United States." All exports are exempt from duties. Laws affecting naturalization and bankruptcies must be uniform. All enjoy the privilege of the writ of habeas corpus, and are alike protected from bills of attainder and ex post facto laws. All are to be mere citizens, free from the overshadowing influence of a nobility. The revenues of the people may be drawn from the public treasury only by means of appropri- 
ations made by law. The courts exist for all, including even aliens, without discrimination. All, when charged with crime, are alike protected in their right of trial by jury where the crime was committed. The citizens of each State are entitled to all the privileges and immunities of citizens in the several States. Nothing is supreme but the law of the land.

Such, in substance, was the Constitution as first adopted. It contemplated a government of uniform laws over citizens with equal rights. Even its guaranties were not accepted as adequate. The victors in a struggle of a thousand years against arbitrary power were unwilling to leave anything to implication. The people demanded that the results of that struggle should be embodied in their fundamental law. Hence the Bill of Rights was at once added by amendment. Thus, by the amended Constitution, all white men secured freedom of religion; freedom of speech; freedom of the press ; freedom of assembly; the right of petition; the right to bear arms; the right to be secure in their persons, houses, papers, and effects; the right of trial by jury in criminal proceedings and in suits at common law; exemption from prosecution for infamous crimes, unless on presentment or indictment of a grand jury; security from being placed twice in jeopardy for the same offense; security from being required in criminal causes to be witnesses against themselves; the right of speedy and public trial by an impartial jury in all criminal prosecutions within the State and district where the crime is committed; the.right, when charged with crime, to be informed of the nature and cause of the accusation, to be confronted with the witnesses for the prosecution, to have compulsory process to compel the attendance of witnesses in their favor, and to have the assistance of counsel for their defense; freedom from excessive bail, from excessive fines, and from cruel and unjust punishments; freedom from the taking of private property for public use without just compensation; and freedom from deprivation of life, liberty, or property, without due process of law.

Even this inventory of personal rights, each term of which is the title to a chapter in the story of constitutional liberty, was not regarded as inclusive. The Ninth Amendment states that "The enumeration in the Constitution, of certain rights, shall not be construed to deny or disparage others retained by the people." Still the ideals of equality and of government by consent were but imperfectly realized. Human slavery, a monstrous anachronism, survived to give the lie to our fair pro- 
fessions of equality. A people that had renounced the institutions of king and nobility could not long look upon slavery without moral disquietude. Having escaped an aristocracy, they could not long tolerate slavery. The noble vision of equality of rights vouchsafed to the fathers inspired their children to strive for its realization. The Revolution witnesses what the fathers dared that they might set up the ideal of equality. The mighty tragedy of civil war forever records what their sons suffered to realize that ideal.

The revolutionists at the outset declared their splendid vision of equality of rights. In their hour of triumph they paused to set up a tabernacle to liberty, to record in the people's grant of power to a government expressive of their authority the personal rights already won. In their hour of triumph the victors of 1865 placed in the Constitution new guaranties of equality.

The Thirteenth Amendment declares that neither slavery nor involuntary servitude, except as a punishment for crime whereof the party shall have been duly convicted, shall exist within the United States, or any place subject to their jurisdiction. The Fourteenth Amendment makes all persons born or naturalized in the United States citizens thereof and of the State wherein they reside. It also provides that no State shall make or enforce any law which shall abridge the privileges or immunities of citizens of the United States; nor deprive any person of life, liberty, or property, without due process of law; nor deny to any person within its jurisdiction the equal protection of the laws. The Fifteenth Amendment declares that the right of citizens of the United States to vote shall not be denied or abridged on account of race, color, or previous condition of servitude.

The Constitution of the fathers established the equality of white men. The great charter of liberty, as it came from the furnace of civil war, proclaimed equality for all men irrespective of race or color. Thus equality of rights, the ideal of the Decldration, became the achievement of the Constitution. Thus a lofty sentiment was realized in the fundamental law of the land.

The events of two years have brought us some grave questions. Shall the evolution of American liberty be reversed? Shall the movement, begun by the adoption of the Constitution and continued in unbroken progress in its amendments, be stayed? Shall we no longer interpret the Constitution in the 
terms of liberty? Shall the President and Congress govern men without their consent? Shall the representatives of a free people act for others than those represented? Shall the creatures of the Constitution exercise any power anywhere outside and in disregard of its limitations? Shall we make rights a mere matter of might and locality? Shall we make inequality of rights, by amendment or evasion of the Constitution, lawful under the American flag?

The "grave departure from right principles" which gives rise to these inquiries is not a mere remote possibility. The executive and legislative branches of the government have done and are doing their utmost to make it an accomplished fact. It is the essence of the Porto Rican legislation. It lies at the bottom of the Administration's Philippine policy. Thousands of lives have been sacrificed and hundreds of millions of the people's earnings squandered in its pursuit. A vast naval and military establishment, one of the costliest in the world, is being provided by a perversion of constitutional powers as a means for a career of conquest. Each step is accompanied by an apology, coupled with a protest that it does not involve the next. Today the President, backed by Congress, stands at the bar of the Supreme Court demanding complete exemption from constitutional control in the government of the territories of the United States and in the acquisition of unlimited possessions for other than constitutional purposes. This demand, if granted, means equal rights for all under the Constitution while within the States and inequality of rights for all under a congressional absolutism when outside the States.

The Secretary of War, in his report for 1899, says:

"I assume *** that the United States has all the powers in respect of a territory it has thus acquired, and the inhabitants of that territory, which any nation in the world has in respect of territory which it has acquired; that, as between the people of the ceded islands and the United States, the former are subject to the complete sovereignty of the latter, controlled by no legal limitations except those which may be found in the treaty of cession; that the people of the islands have no right to have them treated as States, or to have them treated as the territories previously held by the United States have been treated, or to assert a legal right under the provisions of the Constitution, * * * or to assert against the United States any legal. right whaterer not found in the treaty."

The Outlook, a leading exponent of the new policy, declares that the United States "must take such place as its position, 
its character, and its powers entitle it to assume among the nations of the earth; *** that it ought not to confine its interests or limit its duties by any geographical consideration whatsoever; that it ought to share with the world powers in the government of the world."

These quotations fairly represent the thought and purpose of those who would reintroduce into our system the doctrine of inequality of rights. True, they have again and again irrelevantly declared it to be their intention to exercise absolute power over the inhabitants of the ceded islands in a spirit of subjective benevolence. Thus, Secretary Root, in the report above quoted, adds:

"The people of the ceded islands have acquired a moral right to be treated by the United States in accordance with the underlying principles of justice and freedom, which we have declared in our Constitution, which are the essential safeguards of every individual against the powers of government, not because those provisions were enacted for them, but because they are essential limitations inherent in the very existence of American government."

Mr. McKinley himself continues to make profuse though vague promises in recognition of what Mr. Root concedes to be the "moral right" of the Filipinos to be treated by the United States in accordance with the principles of justice and freedom. From his early promise of "a government which will bring them blessings" down to the recitals in his last annual message, these new "wards of the nation" may read of "the benefits of liberty and good government" which he says shall be theirs "in the interests of humanity," of the moral rights which by grace they are to acquire. By military order, through the Secretary of War, he exhorts his present Philippine Commissioners to "bear in mind that the government which they are establishing is designed not for our satisfaction, or for the expression of our theoretical views, but for the happiness, peace, and prosperity of the people of the Philippine Islands."

Mr. McKinley, by the same order, declares it to be his paternal will that-

"the people of the islands be made plainly to understand that there are certain great principles of government, which have been made the basis of our governmental system, which we deem essential to the rule of law and the maintenance of individual freedom, and of which they have, unfortunately, been denied the experience possessed by us; that there are also certain practical rules of government which we have found to be 
essential to the preservation of these great principles of liberty and law; and that these principles and these rules of government must be established and maintained in their islands for the sake of their liberty and their happiness, however much they may conflict with the customs or laws of procedure with which they are familiar. * * Upon every division and branch of the Government of the Philippines, therefore, must be imposed these inviolable rules:

"That no person shall be deprived of life, liberty, or property, without due process of law; that private property shall not be taken for public use without just compensation; that in all criminal prosecutions the accused shall enjoy the right to a speedy and public trial, to be informed of the nature and cause of the accusation, to be confronted with the witnesees against him, to have compulsory process for obtaining witnesses in his favor, and to have the assistance of counsel for his defense; that excessive bail shall not be required, nor excessive fines imposed, nor cruel and unusual punishments inflicted; that no person shall be put twice in jeopardy for the same offense, or be compelled in any criminal case to be a witness against himself; that the right to be secure against unreasonable searches and seizures shall not be violated; that neither slavery nor involuntary servitude shall exist except as a punishment for crime; that no bill of attainder or ex post facto law shall be passed; that no law shall be passed abridging the freedom of speech or of the press, or the rights of the people to peaceably assemble and petition the Government for a redress of grierances; that no law shall be made respecting an establishment of religion or prohibiting the free exercise thereof; and that the free exercise and enjoyment of religious profession and worship without discrimination and preference shall forever be allowed."

These representative citations are here given to exhibit the spirit in which it is proposed to bestow what is called "good government" on all citizens of the United States while outside the States. Upon them, as "wards of the nation," are to fall by grace selected "moral rights" in name akin to some of the equal and inalienable rights of citizens while within the States.

Mr. Hoar has made final answer to the proposal to bestow upon these new "wards" by grace some part of what is the right of every free man. In his great speech of April 17th in the Senate, he says:

"Our imperialistic friends seem to have forgotten the use of the vocabulary of liberty. They talk about giving good government. * * * Why, Mr. President, that one phrase conveys to a free man and a free people the most stinging of insults. In that little phrase, as in a seed, is contained the germ of all despotism and of all tyranny. Government is not 
a gift. Free government is not to be given by all the blended powers of earth and heaven. It is a birthright. It belongs, as our fathers said, and as their children said, ${ }_{*}^{*} *$ to human nature itself.; There can be no good government but selfgovernment."

Whence comes the authority of any man, or group of men, to select from and quarry out of the Constitution rights for gracious bestowal on the people of the territories and islands of the United States? By what warrant does any man, or group of men, in America presume to make of the inalienable rights of free men a mere question of might, only a matter of locality? Whence does any man, or group of men, derive authority to place limitations on the application of the Bill of Rights, to deny equality of rights under the Constitution of the United States?

Those who in our time profess inherent authority to make of liberty itself a gift to other men now come, as tyrants have ever come, with honeyed words upon their lips. If we may credit some fine professions now current in high places, the denial of equality of constitutional rights to the people of the territories and islands of the United States is merely to clear the way for the bestowal of analogous "moral rights" at such times and in such doses as the donors in their superior wisdom deem the donees strong enough to bear. Equality of rights is not denied to the inhabitants of the Spanish islands in order by grace to bestow upon them the immunities and privileges enjoyed under the Constitution by the citizens of the States. On the contrary, equality of rights is denied in order that the President and Congress may govern these islands by power as absolute as is any where known. Indeed, Mr. Root, as we have seen, declares that the United States (meaning the President and Congress) have all the powers which any nation in the world has in respect to acquired territory. That is, they may govern it by power as absolute as that wielded by the Russian Czar.

Note carefully the studied omissions from Mr. McKinley's expurgated version of the Bill of Rights set out above. By these omissions the Filipinos are denied many of the most sacred rights of free men. They may be taxed without representation and without regard to uniformity. Their revenues may be expended without authority of public law. They are denied the right to bear arms. They are denied the right of trial by jury in criminal proceedings as well as in suits at law. 
They may be prosecuted for infamous crimes without presentment or indictment of a grand jury. The speedy and public trial which is promised may be by court-martial ordered to sit anywhere, however remote from the place where the crime was committed. The privilege of the writ of habeas corpus is denied. There is for them no equal protection of the laws.

Even the "moral right" of the new "wards of the nation" to be treated in accordance with the principles of justice and freedom is, it seems, subject to important and wholly arbitrary limitations. The power to bestow involves the power to deny. The power to grant involves the power to withdraw. What may be granted or withheld may be withdrawn or abridged.

The policy thus disclosed and now applied offers to the inhabitants of the ceded islands no shield but benevolenceagainst wrong, no constitutional protection, no hope of liberty. It seeks by force to establish government without consent, taxation without representation, tyranny by the crowd. It means the government of men by arbitrary power. This is imperialism.

The novel assumption that mere agencies of constitutional government may exercise powers beyond the domain of the Constitution, and the proposal by this means to reintroduce into our system the principle of inequality of rights, must now meet the scrutiny of the Supreme Court of the United States. That great tribunal has again and again treated the Constitution as applicable to the territories, and therein applied it for the protection of personal rights. Chief Justice Marshall himself has defined the term "United States" to be "the name given to our great Republic, which is composed of States and Territories." (Loughborough v. Blake, 5 Wheat. 315, 317.) The Court, in deciding that duties collected in California atter its cession to the United States and prior to the establishment therein of a collection district were not illegally exacted, held that: "By the ratification of the treaty, California became a part of the United States"; that commerce "became instantly bound and privileged by the laws which Congress had passed to raise a revenue from duties on imposts and tonnage"; that "the right claimed to land foreign goods within the United States at any place out of a collection district, if allowed, would be a violation of that provision in the Constitution which enjoins that all duties, imposts and excises shall be uniform throughout the United States"; that "there was nothing in the condition of California to exempt importers of 
foreign goods into it from the payment of the same duties which were chargeable in the other ports of the United States"; that "the ratification of the treaty made California a part of the United States, and that as soon as it became so the territory became subject to the acts which were in force to regulate foreign commerce with the United States." (Cross v. Harrison, 16 How. 164, 198.)

A distinction, often overlooked, lies between personal and political rights. Congress possesses the same general powers, subject to like limitations, over the territories and their inhabitants that it possesses over the States and their inhabitants. In addition to these general powers, it possesses in the territories the same powers, subject to like limitations, over local affairs as the States possess over local affairs. Thus Congress holds in the territories the sum of national and local legislative powers, subject to the limitations of the Constitution.

The Supreme Court, as late as 1884, said :

"The personal and civil rights of the inhabitants of the territories are secured to them, as to other citizens, by the principles of constitutional liberty which restrain all the agencies of government, State and national; their political rights are franchises which they hold as privileges in the legislative discretion of the Congress of the United States." (Murphy v. Ramsey, 114 U. S. 15.)

The Court, in pursuance of this distinction, has held that "the provisions of the Constitution relating to trials by jury for crimes and to criminal processes apply to the territories of the United States" (Thompson v. Utah, 170 U.S. 343, 346; Callan v. Wilson, 127 U. S. 1540); that Congress in legislating for the territories and the District of Columbia is subject to those fundamental limitations in favor of personal and civil rights which are formulated in the Constitution and its Amendments (Mormon Church v. United States, 136 U. S. 1; McAllister v. United States, 141 U. S. 174; American Publishing Society v. Fisher, 166 U.S. 464, 466); and that the United States, upon "acquiring territory by treaty or otherwise, must hold it subject to the Constitution and laws." (Pollard $\mathrm{v}$. Hagan, 3 How. 312.)

When it is said that Congress has absolute power to legislate respecting the territories of the United States, what is meant, as we have seen, is that Congress holds the sum of national and local legislative powers in respect of such territories. It may do in a territory, in addition to what it may do 
in a State, what the people of a State acting through their general assembly may do in that State. The Supreme Court has held that the form of government to be established in a territory rests in the discretion of Congress,

"acting within the scope of its constitutional authority, and not infringing upon the rights of persons or rights of property of the citizen. * * * The power of Congress over the person or property of a citizen can never be a mere discretionary power under our Constitution and form of government. The powers of government and the rights and privileges of the citizen are regulated and plainly defined by the Constitution itself. And when the territory becomes a part of the United States the Federal Government enters into possession in the character impressed upon it by those who created it. It enters upon it with its powers over the citizen strictly defined, and limited by the Constitution, from which it derives its own existence, and by virtue of which alone it continues to exist and act as a government and sovereignty. It has no power of any kind beyond it; and it cannot, when it enters a territory of the United States, put off its character, and assume discretionary or despotic powers which the Constitution has denied it. It cannot create for itself a new character separated from the citizens of the United States and the duties it owes them under the provisions of the Constitution. The territory being a part of the United States, the government and the citizens both enter it under the authority of the Constitution, with their respective rights defined and marked out; and the Federal Government can exercise no power over his person or property, beyond what that instrument confers, nor lawfully deny any right which it has reserved.

"The powers over person and property of which we speak are not only not granted to Congress, but are in express terms denied, and they are forbidden to exercise them. And this prohibition is not confined to the States, but the words are general and extend to the whole territory over which the Constitution gives it power to legislate." (Scott v. Sandford, 19 How. 393, 449.)

The Court, in the same case, says :

"A power, therefore, in the general government to obtain and hold colonies and dependent territories, over which they might legislate without restriction, would be inconsistent with its own existence in its present form." (Id., p. 448.)

The attempt, by the terms of the treaty itself, to enlarge the powers of Congress by conferring upon it power to determine "the civil rights and political status of the native inhabit- 
ants" of the islands, is without effect. The Supreme Court, in the case of New Orleans v. United States (10 Pet. 662, 736), says :

"The Government of the United States is one of limited powers. It can exercise authority over no subjects except those which have been delegated to it. Congress cannot, by legislation, enlarge the Federal jurisdiction, nor can it be enlarged by the treaty-making power."

The Court, in the case of Pollard v. Hagan (3 How. $212,225)$, says :

"It cannot be admitted that the King of Spain could, by treaty or otherwise, impart to the United States any of his royal prerogatives; and much less can it be admitted that they have capacity to receive or power to exercise them. Every nation acquiring territory, by treaty or otherwise, must hold it subject to the constitution and laws of its own government."

It may be conceded, for the sake of argument, that Congress may determine the status of the present inhabitants of the ceded islands, but the Fourteenth Amendment fixes the status of all persons born therein after the date of cession. The Court, in the recent case of United States v. Wong Kim Ark (169 U.S. 649, 703), held that American-born Chinamen of alien parentage are citizens of the United States free from the provisions of the exclusion acts and treaties; and that Congress is without power "to restrict the effect of birth, declared by the Constitution to constitute a sufficient and complete right of citizenship."

Even the question of citizenship does not determine personal and property rights under the Constitution. The Supreme Court, in the late case of Lem Moon Sing v. United States (158 U.S. 538, 547), in passing on the rights of a Chinese alien in the United States, said:

"While he lawfully remains here he is entitled to the benefit of the guaranties of life, liberty and property, secured by the Constitution to all persons, of whatever race, within the jurisdiction of the United States. His personal rights when he is in this country, and such of his property as is here during his absence, are as fully protected by the supreme law of the land as if he were a rative or naturalized citizen of the United States."

This brief review of the authorities makes it clear that the Supreme Court, in the discharge of its highest function, has steadily interpreted the Constitution in the terms of liberty, giving full effect to its purpose to establish equality of rights 
for all men in all places within the jurisdiction of the United States.

The proposal, despite such a Constitution so achieved and thus interpreted, to reintroduce into our system the principle of inequality of rights, the assertion of a purpose to make God's liberty a matter of locality instead of personal right, is indeed shocking. Even the assumed interests of trade cannot impart lasting vitality to a purpose whose merits may not be discussed in the presence of free men. We made tremendous sacrifices to destroy the inequality of slavery, to make the ideal of equality declared by the fathers the highest achievement of constitutional liberty. We suffered much that the Union might cease to be divided, that all men within the jurisdiction of the United States, irrespective of race or color, might have equal personal rights. The argument that, having sinned against liberty in our treatment of the negro, we may now betray liberty in the person of the Filipino for a possible commercial profit, is but for the moment, and to cover an awful blunder. The Constitution lives as the supreme law of the land. It does not admit, what ex-President Harrison has justly characterized, "a construction contrary to liberty." It can neither be amended nor long evaded to promote inequality of rights. Nothing short of equality of rights for all men as men in all places within the jurisdiction of the United States can be the purpose of American law. 